Article

\title{
Drying Kinetics, Grinding Characteristics, and Physicochemical Properties of Broccoli Sprouts
}

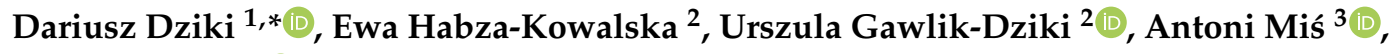 \\ Renata Różyło $^{4}{ }^{\circledR}$, Zbigniew Krzysiak ${ }^{5}$ and Waleed H. Hassoon ${ }^{1,6}$ \\ 1 Department of Thermal Technology and Food Process Engineering, University of Life Sciences in Lublin, \\ Głęboka 31, 20-612 Lublin, Poland; waleedww27@yahoo.com \\ 2 Department of Biochemistry and Food Chemistry, University of Life Sciences, Skromna 8, 20-704 Lublin, \\ Poland; ewa.habza1@gmail.com (E.H.-K.); urszula.gawlik@up.lublin.pl (U.G.-D.) \\ 3 Institute of Agrophysics, Polish Academy of Sciences, Doświadczalna 4, 20-290 Lublin, Poland; \\ a.mis@ipan.lublin.pl \\ 4 Department of Equipment Operation and Maintenance in the Food Industry, University of Life Sciences, \\ Głęboka 28, 20-612 Lublin, Poland; renata.rozylo@up.lublin.pl \\ 5 Department of Mechanical Engineering and Automatics, University of Life Sciences, Głęboka 28, \\ 20-612 Lublin, Poland; zbigniew.krzysiak@up.lublin.pl \\ 6 Department of Food Technology, College of Food Sciences, University of Al-Qasim Green, Babylon 964, Iraq \\ * Correspondence: dariusz.dziki@up.lublin.pl
}

Received: 7 December 2019; Accepted: 8 January 2020; Published: 10 January 2020

check for updates

\begin{abstract}
In this study, we studied the drying process, grinding characteristics and physicochemical characteristics of broccoli sprouts (BS). The seeds of broccoli were germinated at $20^{\circ} \mathrm{C}$ for 3 and 6 days. Then, the seeds were air- and freeze-dried, and the Page model was used for prediction of drying kinetics of broccoli sprouts. It was observed that the drying time of BS decreased about twofold as the air-drying temperature increased from 40 to $80^{\circ} \mathrm{C}$. An increasing the air-drying temperature from 40 to $80{ }^{\circ} \mathrm{C}$ decreased the drying time by approximately twofold. Freeze-drying of sprouts took the longest drying time. Germination of seeds significantly decreased the value of grinding energy requirements, and the ground sprouts exhibited a different grinding pattern in comparison to ground non-germinated seeds. In terms of color parameters, the highest lightness and yellowness were found for freeze-dried sprouts. Redness and yellowness of sprouts increased with an increase in the air-drying temperature. The lowest total color difference was obtained for the freeze-dried sprouts. Higher drying temperature resulted in lower total phenolics content (TPC) and decreased antioxidant activity (AA). The highest TPC and AA were observed in air-dried sprouts $\left(40^{\circ} \mathrm{C}\right)$ and freeze-dried sprouts after 6 days of germination.
\end{abstract}

Keywords: broccoli; germination; air-drying; freeze-drying; temperature; grinding energy; total phenolics content

\section{Introduction}

Cruciferous are common vegetables popularly used as food but also used in traditional medicines. They are recognized as functional foods because of their preventive role against various diseases in addition to providing nutrition to the body [1]. Among all the cruciferous vegetables, especially broccoli (Brassica oleracea L.) contains diverse bioactive compounds with chemopreventive effects, such as isothiocyanates (especially sulforaphane), but also others, such as anthocyanins, glucosinolates, phenolics, flavonoids and vitamins [2-5]. These compounds have considerable health benefits to the consumer [5]. 
During germination antioxidant properties of seed are enhanced and the nutrient inhibitors are hydrolyzed, thereby releasing micronutrients, phosphate and vitamins [6-8]. Moreover, this process stimulates various reactions and promotes the formation of new compounds, especially B-vitamins, phenolics and gamma aminobutyric acid [6]. Moreover, it reduces the level of antinutrients present in the seed and increases the availability of minerals [9].

Production of sprouts is simple and inexpensive [10]. Sprouts are one of the valuable alternatives of increasing the consumption of seeds, which provide higher nutritive value than seeds. Especially broccoli sprouts are considered as a functional food as a result of the presence high level of vitamins, phenolic compounds and glucosinolates [11-13]. Moreover, the broccoli sprouts are inducers of detoxifying enzymes and are rich in sulforaphane, which protect against carcinogens $[14,15]$. Furthermore, one-week consumption of the broccoli sprouts has shown to improve the metabolism of cholesterol and reduce oxidative stress [16,17].

Sprouts as fresh food are characterized by short shelf life due to high water activity. Drying is one of the best methods of food preservation. It allows for a longer period of storage and minimizes the requirements of packing, transport, handling, and distribution $[18,19]$. The quality of dried sprouts is determined based on drying conditions and methods. In particular, conditions of sprouts drying must be chosen to preserve bioactive compounds and their nutritive value [20,21].

Grinding is very important unit operation in food processing. This process allows obtaining appropriate size of particles for subsequent processes [22] but also increases nutritional and functional properties of foods $[23,24]$. For example, size reduction of broccoli floret tissue positively influenced on the extraction of vitamin $C$ and antioxidants properties of broccoli florets $[25,26]$.

To our best knowledge, the drying and grinding processes of broccoli sprouts were not studied so far. Therefore, the aim of this study was to quantify the air-drying and freeze-drying kinetics of broccoli sprouts, as well as to study the effect on drying on total phenolics content, antioxidant activity and color changes. The grinding process of dried broccoli sprouts was also studied and the indices characterizing the grinding process of dried broccoli sprouts were calculated.

\section{Materials and Methods}

\subsection{Raw Material}

The experiments were Investigations were conducted on the Polish broccoli cultivar (var. Cezar). Filed experiment was conducted in 2017 in the experiment station in Lublin (Poland). Before germination, seeds of broccoli $(11.5 \%$ wet basis moisture content) were sterilized with $1 \%$ sodium hypochlorite and soaked according to procedure described be Świeca et al. [27]. After soaking, seeds were sown in sprouters (Bio-Natura, Poland, Wrocław). The seeds were germinated under dark conditions for 3 and 6 days at $20^{\circ} \mathrm{C}$ in a climatic chamber (ICH 256, Memmert, Düsseldorf, Germany). During germination, the seeds were watered with distilled water.

\subsection{Moisture Content and Water Activity}

The moisture content in the seeds and sprouts was determined by drying $5 \mathrm{~g}$ samples for $8 \mathrm{~h}$ at $105{ }^{\circ} \mathrm{C}$ [28], and the water activity was evaluated using Labtouch-aw Basic, (Novasina, Lachen, Switzerland).

\subsection{Drying Process}

After germination, the sprouts of broccoli (100 $\mathrm{g}$ of whole seedlings) were air-dried and freeze-dried. The air-drying process was performed at three levels of temperature $\left(40,60\right.$ and $\left.80^{\circ} \mathrm{C}\right)$ with air flowing over the material at a superficial velocity of $0.5 \mathrm{~ms}^{-1}$ by using a laboratory dryer constructed by Promis-Tech (Wroclaw, Poland) [29]. The lyophilization was run by using Martin Christ's dryer ALPHA 1-4 (Martin Christ Gefriertrocknungsanlagen GmbH, Osterode am Harz, Germany) according to the method described by Rudy et al. [30]. Prior to this, the samples of the broccoli sprouts were 
frozen at $-35{ }^{\circ} \mathrm{C}$ for $24 \mathrm{~h}$ in a freezer (MDF-U5412-PE, Panasonic, Osaka, Japan). Frozen sprouts were immediately transferred to the freeze drier. The same weight of the sample $(100 \mathrm{~g})$ was lyophilized each time at $40{ }^{\circ} \mathrm{C}$ and at a pressure of $52 \mathrm{~Pa}$. The weight of the dried samples was recorded both during air-drying and freeze-drying [29,30]. Both processes were continued until the moisture of the samples decreased to $10 \%( \pm 0.5 \%)$ wet basis (w.b.). Based on the values of the weight loss the moisture ratio $(M R)$ was calculated as a ratio of water content $(u)$ during the course of experiment to the initial water content $\left(u_{0}\right)$, using the Formula $(1)$ :

$$
M R=\frac{u}{u_{0}}
$$

The drying curves were charted as function of $M R$ versus time and Page model [31] was proposed to fit the drying curves of broccoli sprouts, using the Formula (2):

$$
M R=\exp \left(-k \tau^{n}\right)
$$

where, $k$ is the drying coefficient $\left(\mathrm{min}^{-1}\right), n$ is the exponent and $\tau$ is the time (min).

This model is often used both to describe freeze-drying and air-drying kinetics of different food [32-35].

On the basis of non-linear regression analysis the parameters of proposed model were determined and $\mathrm{R}^{2}$ (coefficient of determination) and RSME (root mean square error) were determined [36].

\subsection{Grinding Process}

The seeds and the dried sprouts of broccoli (10\% moisture (w.b.)) were ground with a laboratory knife mill (Grindomix GM, Retsch, Düsseldorf, Germany) equipped with two knives that are $1.5 \mathrm{~mm}$ thick at a speed of $7000 \mathrm{rpm}$ during $30 \mathrm{~s}$ and cooperated with electric current measurement system [37]. Sieving analysis of ground sprouts and seeds was performed. The materials were sieved using sieves of various sizes for $3 \mathrm{~min}$ : 0.8, 0.6, 0.4, 0.2 and $0.1 \mathrm{~mm}$ sieve sizes by using a laboratory screen (RS 200, Retsch, Düsseldorf, Germany) and the average particle size of the ground sprouts was determined. Moreover, the grinding following energy indices were calculated: specific grinding energy, grinding ability index and Sokołowski's grinding index [38,39].

\subsection{Color Evaluation}

Three lightness $\left(L^{*}\right)$, redness $\left(a^{*}\right)$ and yellowness $\left(b^{*}\right)$ of the ground seeds and sprouts of broccoli were determined using a Minolta CR-400 colorimeter (Konica-Minolta, Osaka, Japan) [RUDY]. The analyses of the color values were performed six times with each dried sample by placing the sensor on the ground sample. Based on the obtained data, the total color difference $(\Delta E)$ was calculated according to Equation (3) [40]:

$$
\Delta E=\sqrt{\left(L_{c}^{*}-L^{*}\right)^{2}+\left(a_{c}^{*}-a^{*}\right)^{2}+\left(b_{c}^{*}-b^{*}\right)^{2}},
$$

where, the $L_{c}^{*}, a_{c}^{*}$ and $b_{c}^{*}$ are the color parameters of the broccoli seeds, and the $L^{*}, a^{*}$ and $b^{*}$ are the color parameters of the processed broccoli seeds.

\subsection{Total Phenolics Content (TPC) and Antioxidant Activity (AA)}

For the determination TPC and AA, we prepared the extracts from the ground seeds and sprouts according to procedure described by Gawlik-Dziki et al. [41]. The TPC was estimated according to the Folin-Ciocalteau method [42], with slight modification [21].

The following methods of antioxidant activity of the obtained extracts were determined: the ability to chelate metal ions (CHEL) [21,43], the antiradical estimated activity by ABTS (2,2'-azino-bis(3-ethylbenzothiazoline-6-sulphonic acid) method [21,44], quinoa and reducing power [45]. All antioxidant activities were expressed as EC50 (mg DM/mL) [21]. 


\subsection{Statistical Analysis}

We performed germination of the seeds in three independent occasions and calculated the mean and standard deviation. The analysis of variance (ANOVA) was performed and the Tukey's test was used to compare the differences between means at a significance level of $\alpha=0.05$ using Statistica 13.0 by StatSoft.

\section{Results and Discussion}

\subsection{Moisture Content and Water Activity}

The water activity $\left(\mathrm{a}_{\mathrm{w}}\right)$ of fresh broccoli sprouts was $0.999 \pm 0.03$ and moisture content $82.6 \%$ (w.b.). Drying reduced the value of $\mathrm{a}_{\mathrm{w}}$ (between $0.287 \pm 0.04$ (freeze-dried sprouts) and $0.293 \pm 0.06$ (air-dried sprouts at $40^{\circ} \mathrm{C}$ )). Water activity is an important parameter to estimate storage stability of food [46]. Food with $a_{w}<0.6$ is considered as microbiologically stable [47]. According to our results, the $a_{w}$ value of powders prepared from broccoli seeds and sprouts were less than 0.3 , which indicates that the powders were microbiologically stable.

\subsection{Drying Results}

Figure 1 show a comparison of the experimental data and the predicted data related to sprouts drying based on the Page model. The air-drying temperature significantly increased the drying rate (DR), whereas the germination time had a little influence on DR. The average time of sprouts air-drying at temperature of $40^{\circ} \mathrm{C}$ was about $60 \mathrm{~min}$. The drying time decreased approximately twofold with the increase in air temperature up to $80^{\circ} \mathrm{C}$. The longest time of drying was observed during freeze-drying (about $145 \mathrm{~min}$ and $135 \mathrm{~min}$ for seeds germinated for 3 and 6 days, respectively) than that of air-drying. Usually the drying time during freeze-drying is longer when compared to other methods of drying because the sublimation takes a long time [48,49]. Moreover, freeze-drying is time consuming because it is usually performed in low temperature and overheating can cause lower quality of dried material [50].

Table 1 shows the values of the parameters in the Page equations describing the drying kinetics of broccoli sprouts (BS). All the calculated $\mathrm{R}^{2}$ values fell in the range of $0.997-0.999$, whereas the values of RMSE changed from 0.0070 to 0.0208 . It indicated that proposed model well describes the drying kinetics of BS. Especially, the highest values of coefficient of determination and the loves root mean square error were found far air-dried sprouts (SAD40, Table 1) at $40^{\circ} \mathrm{C}$. Moreover, the $k$ coefficient increased with the increasing air drying temperature from 0.0519 to 0.1309 for BS germinated for three days and from 0.052 to 0.9001 for BS germinated from six days. The lowest values of these coefficients were obtained for freeze dried sprouts ( 0.0070 and 0.0055 , respectively). Literature with regard to the drying kinetics of sprouted seeds is limited. Other authors [32] found that drying kinetics of 4-day germinated wheat sprouts was also best described by the Page model.

Table 1. Coefficient values, $R^{2}$ and root mean square error (RSME) in the Page model describing the drying process of broccoli sprouts.

\begin{tabular}{cccccc}
\hline Germination Time (Days) & Drying Method & $\boldsymbol{k}\left(\mathbf{m i n}^{-1}\right)$ & $\mathbf{n}$ & $\mathbf{R}^{\mathbf{2}}$ & $\mathbf{R S M E}$ \\
\hline \multirow{3}{*}{3} & SPD40 & 0.0519 & 0.9368 & 0.999 & 0.00698 \\
& SPD60 & 0.0822 & 0.9584 & 0.997 & 0.01609 \\
& SPD80 & 0.1309 & 0.9215 & 0.998 & 0.02083 \\
& SPF & 0.0070 & 1.2053 & 0.997 & 0.01540 \\
\hline \multirow{2}{*}{6} & SPD40 & 0.0520 & 0.9367 & 0.999 & 0.01495 \\
& SPD60 & 0.0773 & 0.9667 & 0.997 & 0.01687 \\
& SPD80 & 0.9001 & 0.1310 & 0.997 & 0.01262 \\
& SPF & 0.0055 & 1.2469 & 0.997 & 0.01687 \\
\hline
\end{tabular}

SPD40, SPD60 and SPD80—sprouts air dried at 40,60 and $80{ }^{\circ} \mathrm{C}$, respectively, SPF-freeze-dried sprouts. 

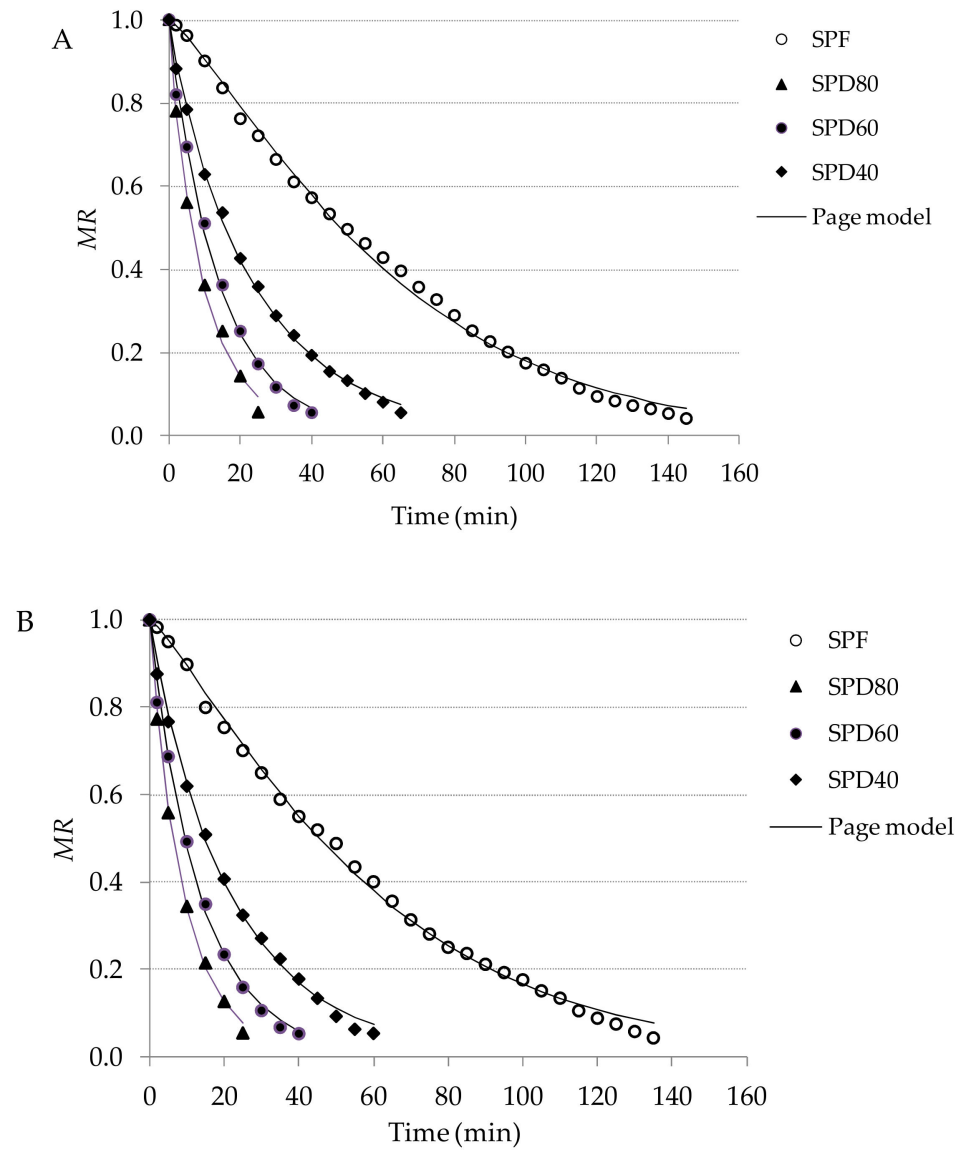

Figure 1. Drying curves of dried broccoli sprouts with experimental and predicted data based on the Page model: $M R$-moisture ratio, SPD40, SPD60 and SPD80-sprouts air-dried at 40, 60 and $80^{\circ} \mathrm{C}$, respectively, SPF—freeze-dried sprouts, (A) —after 3 days of germination and (B) —after 6 days of germination.

\subsection{Grinding Results}

Table 2 presents the granulometric distribution of comminuted particles of BS and seeds. The highest percentage of coarse particles $(>0.8 \mathrm{~mm})$ was obtained in the case of ground broccoli seeds, whereas the lowest percentage was obtained in the case of ground freeze-dried sprouts. We observed a reverse tendency in the case of the smallest particles (below $0.2 \mathrm{~mm}$ ), which indicates that sprouts of broccoli give during size reduction different grinding pattern than broccoli seeds. Similar results were found by others authors for sprouted wheat [32].

Furthermore, the time of germination had a minor influence on the grinding pattern of BS (Table 3 ). Seeds germinated for 6 days were characterized by a slightly lesser quantity of fine particles than that of seeds germinated for 3 days. This might be due to the changes occurring during germination. Sprouting increases activity of different enzymes and it leads to degradation the bran layer and endosperm [51] thereby making the process of grinding more effective. In consequence, the particle size of powdered sprouts was lower than that of ground seeds (Table 3). Similar results were reported by other authors [52] for sprouted wheat. The specific grinding energy ranged from $8.5 \mathrm{~kJ} \mathrm{~kg}^{-1}$ for freeze-dried sprouts after 6-day germination to $12.2 \mathrm{~kJ} \mathrm{~kg}^{-1}$ for seeds. Furthermore, other grinding energy indices confirmed that sprouted seeds of broccoli required less energy for grinding in comparison to non-germinated seeds. The values of grinding ability index ranged from $0.74 \mathrm{~m}^{2} \mathrm{~kJ}^{-1}$ for seeds to $1.26 \mathrm{~m}^{2} \mathrm{~kJ}^{-1}$ for freeze-dried sprouts after 6-day germination, whereas the values of Sokołowski's grinding index changed from $10.5 \mathrm{~kJ} \mathrm{~kg}^{-1} \mathrm{~mm}^{0.5}$ for freeze-dried sprouts after 6-day germination to $17.7 \mathrm{~kJ} \mathrm{~kg}^{-1} \mathrm{~mm}^{0.5}$ for seeds. These results suggest that broccoli sprouts required less energy for grinding in comparison to the values of grinding indices obtained for other seeds or sprouts [33,37]. 
Table 2. Particle size distribution (\%) of ground broccoli seeds and sprouts.

\begin{tabular}{|c|c|c|c|c|c|}
\hline \multirow{2}{*}{$\begin{array}{l}\text { Range of Class, } \\
\text { mm }\end{array}$} & \multirow{2}{*}{ Seeds } & SPD40 & SPD60 & SPD80 & SPF \\
\hline & & \multicolumn{4}{|c|}{ After 3 Days of Germination } \\
\hline$>0.8$ & $8.2 \pm 0.21 \mathrm{fD}$ & $7.1 \pm 0.18^{\mathrm{fC}}$ & $6.9 \pm 0.15^{b C}$ & $5.8 \pm 0.11^{\mathrm{fB}}$ & $4.9 \pm 0.08^{\mathrm{aA}}$ \\
\hline $0.6-0.8$ & $21.9 \pm 0.53 \mathrm{eC}$ & $8.8 \pm 0.26^{\mathrm{eA}}$ & $8.0 \pm 0.45^{\mathrm{eA}}$ & $8.8 \pm 0.36^{\mathrm{eA}}$ & $8.5 \pm 0.87^{\mathrm{eB}}$ \\
\hline $0.4-0.6$ & $35.8 \pm 0.79 \mathrm{dA}$ & $39.6 \pm 1.12 \mathrm{~dB}$ & $42.1 \pm 1.18 \mathrm{dC}$ & $43.2 \pm 1.36 \mathrm{dC}$ & $43.6 \pm 1.02 \mathrm{~dB}$ \\
\hline $0.2-0.4$ & $28.9 \pm 0.63^{\mathrm{cA}}$ & $35.1 \pm 0.99 \mathrm{cD}$ & $33.3 \pm 1.32^{\mathrm{cC}}$ & $32.6 \pm 1.18^{\mathrm{cC}}$ & $31.6 \pm 0.65^{\mathrm{cB}}$ \\
\hline $0.1-0.2$ & $4.1 \pm 0.11 \mathrm{bB}$ & $7.2 \pm 0.11^{b C}$ & $6.9 \pm 0.13^{b C D}$ & $7.4 \pm 0.08^{\mathrm{bA}}$ & $7.3 \pm 0.21 \mathrm{bD}$ \\
\hline \multirow[t]{2}{*}{$<0.1$} & $1.1 \pm 0.08^{\mathrm{aA}}$ & $2.2 \pm 0.05^{\mathrm{aB}}$ & $2.8 \pm 0.11^{\mathrm{aC}}$ & $2.2 \pm 0.07^{\mathrm{aB}}$ & $4.1 \pm 0.19 \mathrm{bD}$ \\
\hline & & \multicolumn{4}{|c|}{ After 6 days of germination } \\
\hline$>0.8$ & $8.2 \pm 0.21^{\mathrm{fD}}$ & $6.7 \pm 0.26^{\mathrm{fC}}$ & $6.6 \pm 0.31^{b C}$ & $5.4 \pm 0.23^{\mathrm{fB}}$ & $4.3 \pm 0.18^{\mathrm{aA}}$ \\
\hline $0.6-0.8$ & $21.9 \pm 0.53^{\mathrm{eC}}$ & $8.7 \pm 0.33^{\mathrm{eA}}$ & $8.2 \pm 0.38^{\mathrm{eA}}$ & $8.9 \pm 0.31^{\mathrm{eA}}$ & $8.3 \pm 0.65^{\mathrm{eB}}$ \\
\hline $0.4-0.6$ & $35.8 \pm 0.79 \mathrm{dA}$ & $41.3 \pm 1.26 \mathrm{~dB}$ & $41.6 \pm 1.72 \mathrm{dC}$ & $42.1 \pm 1.88 \mathrm{dC}$ & $43.5 \pm 1.13^{\mathrm{dB}}$ \\
\hline $0.2-0.4$ & $28.9 \pm 0.63^{\mathrm{cA}}$ & $33.2 \pm 1.28^{\mathrm{cD}}$ & $33.5 \pm 1.32^{\mathrm{cD}}$ & $33.8 \pm 1.18^{\mathrm{cD}}$ & $31.2 \pm 0.82^{\mathrm{cB}}$ \\
\hline $0.1-0.2$ & $4.1 \pm 0.11 \mathrm{bB}$ & $6.6 \pm 0.23 \mathrm{bC}$ & $6.6 \pm 0.18^{\mathrm{bCD}}$ & $7.2 \pm 0.14^{\mathrm{bA}}$ & $6.9 \pm 0.19 \mathrm{bD}$ \\
\hline$<0.1$ & $1.1 \pm 0.08^{\mathrm{aA}}$ & $2.5 \pm 0.07^{\mathrm{aB}}$ & $3.5 \pm 0.12^{\mathrm{aC}}$ & $2.6 \pm 0.11^{\mathrm{aB}}$ & $4.8 \pm 0.23 \mathrm{bD}$ \\
\hline
\end{tabular}

SPD40, SPD60 and SPD80-sprouts air dried at 40,60 and $80{ }^{\circ} \mathrm{C}$, respectively, SPF-freeze-dried sprouts, small different letters in the columns and capital different letters in rows mean significant differences between means, respectively $(\alpha=0.05)$.

Table 3. Average particle size (d) and grinding energy indices of ground broccoli seeds and sprouts.

\begin{tabular}{|c|c|c|c|c|c|}
\hline Sample & $\begin{array}{c}\text { Time of Germination } \\
\text { (Days) }\end{array}$ & $d_{p}(\mathrm{~mm})$ & $E_{r}\left(\mathrm{~kJ} \mathrm{~kg}^{-1}\right)$ & $E_{f}\left(\mathrm{~m}^{2} \mathrm{~kJ}^{-1}\right)$ & $\begin{array}{c}K_{s} \\
\left(\mathrm{~kJ} \mathrm{~kg}^{-1} \mathrm{~mm}^{0.5}\right)\end{array}$ \\
\hline Seeds & - & $0.508 \pm 0.026^{b}$ & $12.2 \pm 0.63^{d}$ & $0.74 \pm 0.042^{\mathrm{a}}$ & $17.7 \pm 0.92^{\mathrm{e}}$ \\
\hline \multirow{2}{*}{ SPD40 } & 3 & $0.457 \pm 0.011^{b}$ & $10.5 \pm 0.57^{c}$ & $0.98 \pm 0.051^{b}$ & $13.5 \pm 0.56^{\mathrm{d}}$ \\
\hline & 6 & $0.452 \pm 0.008^{b}$ & $10.1 \pm 0.51^{\mathrm{c}}$ & $1.03 \pm 0.055 b c$ & $12.8 \pm 0.84^{\mathrm{cd}}$ \\
\hline \multirow{2}{*}{ SPD60 } & 3 & $0.449 \pm 0.013^{a b}$ & $9.8 \pm 0.46^{c}$ & $1.05 \pm 0.017^{b c}$ & $12.6 \pm 0.78^{c}$ \\
\hline & 6 & $0.447 \pm 0.007^{a b}$ & $9.5 \pm 0.35 \mathrm{bc}$ & $1.09 \pm 0.056^{b c}$ & $12.2 \pm 0.61 \mathrm{bc}$ \\
\hline \multirow{2}{*}{ SPD80 } & 3 & $0.449 \pm 0.023^{a b}$ & $9.5 \pm 0.34^{b}$ & $1.08 \pm 0.062^{b c}$ & $12.2 \pm 0.43^{b c}$ \\
\hline & 6 & $0.445 \pm 0.027^{\mathrm{ab}}$ & $9.4 \pm 0.44^{b}$ & $1.10 \pm 0.068^{b c}$ & $12.0 \pm 0.72 \mathrm{bc}$ \\
\hline \multirow{2}{*}{ SPF } & 3 & $0.434 \pm 0.013^{a}$ & $9.1 \pm 0.42^{\mathrm{ab}}$ & $1.16 \pm 0.049^{c}$ & $11.4 \pm 0.35^{b}$ \\
\hline & 6 & $0.430 \pm 0.01^{2 \mathrm{a}}$ & $8.5 \pm 0.38^{a}$ & $1.26 \pm 0.073^{d}$ & $10.5 \pm 0.37^{a}$ \\
\hline
\end{tabular}

SPD40, SPD60 and SPD80-sprouts air-dried at 40,60 and $80^{\circ} \mathrm{C}$, respectively, SPF-freeze-dried sprouts, $d_{p}$-average particle size, $E_{r}$-specific grinding energy, $E_{f}$-grinding efficiency index, $S_{\mathrm{k}}$-Sokołowski's grinding index. The values designated by the different letters are significantly different $(\alpha=0.05)$.

The air drying temperature in the range of $40-60^{\circ} \mathrm{C}$ had no significant influence on the average particle size and grinding energy indices of BS. An increase in the drying temperature to up $80^{\circ} \mathrm{C}$ caused the grinding process more effective and lower values of average particle size and specific grinding energy were obtained in comparison to the values of these indices obtained for sprouts dried at $40{ }^{\circ} \mathrm{C}$ (Table 3). Drying of seeds in higher temperature decreases their strength properties [53] and as a result of this the grinding process of such material is more effective. Probably the similar phenomenon occurred if sprouts dried in higher temperature.

\subsection{Color}

Table 4 shows the values of color coordinates of the ground seeds and sprouts. The highest value for lightness $\left(L^{*}\right)$ was obtained for freeze-dried sprouts and seeds (average $L^{*}=61$ ). Air-drying decreased the lightness of broccoli sprouts. Redness and yellowness were found to 2.6-8.6 and 28.2-32.2, respectively. The lowest value of redness and the highest value of yellowness were obtained for freeze-dried sprouts, whereas the highest redness and the lowest value of yellowness were obtained for air-dried sprouts. Time of germination had less influence on the color coordinates of BS. The lowest values of $L^{*}$ were observed when sprouts were dried at 40 and $60^{\circ} \mathrm{C}$ (average $L^{*}=43.8$ ). It was 
found that as the air-drying temperature increased, the lightness of sprouts slightly but significantly increased up to 45.2 (average value of $L^{*}$ for 3 days and 6 days germinated seeds). The total difference of color $(\Delta \mathrm{E})$ between the seeds and sprouts ranged from 4.4 to 17.1 and increased with the increase of air-drying temperature from 60 to $80^{\circ} \mathrm{C}$. The value of $\Delta \mathrm{E}$ above 3.5 shows a clear difference in color [54]. The highest value of $\Delta \mathrm{E}$ was obtained for air-dried spouts at 40 and $60^{\circ} \mathrm{C}$. With an increase in the air-drying temperature from 60 to $80{ }^{\circ} \mathrm{C}$, there was a decrease in the value of $\Delta \mathrm{E}$. Other studies have also confirmed that drying time, temperature and drying methods strongly affect the color parameters of dried food [30,55]. Usually, the longer the drying time, the more deterioration of the color takes place in the dried material [55]. Moreover, freeze drying is one of the best methods to keep the natural color of dried foods [56]. In our study also the lowest value of $\Delta \mathrm{E}$ was obtained for freeze-dried sprouts. Color changes in dried biological materials are mainly caused by the degradation of pigments and the formation of brown pigments by Maillard and enzymatic reactions [57].

Table 4. Color coordinates of the ground seeds and sprouts and total color difference $(\Delta E)$.

\begin{tabular}{cccccc}
\hline Sample & Germination Time (Days) & $\boldsymbol{L}^{*}(\mathbf{m m})$ & $\boldsymbol{a}^{*}$ & $\boldsymbol{b}^{*}$ & $\boldsymbol{\Delta}$ \\
\hline Seeds & - & $59.9 \pm 1.28^{\mathrm{b}}$ & $6.7 \pm 0.23^{\mathrm{d}}$ & $30.9 \pm 1.22^{\mathrm{dc}}$ & - \\
\hline \multirow{2}{*}{ SPD40 } & 3 & $44.6 \pm 1.16^{\mathrm{a}}$ & $7.8 \pm 0.31^{\mathrm{e}}$ & $29.1 \pm 1.17^{\mathrm{bc}}$ & $15.4 \pm 0.37^{\mathrm{c}}$ \\
& 6 & $43.1 \pm 1.52^{\mathrm{a}}$ & $7.3 \pm 0.25^{\mathrm{e}}$ & $28.2 \pm 1.31^{\mathrm{ab}}$ & $17.1 \pm 0.46^{\mathrm{d}}$ \\
\hline \multirow{2}{*}{ SPD60 } & 3 & $44.2 \pm 1.23^{\mathrm{a}}$ & $4.8 \pm 0.18^{\mathrm{c}}$ & $27.8 \pm 1.28^{\mathrm{a}}$ & $16.4 \pm 0.58^{\mathrm{d}}$ \\
& 6 & $43.2 \pm 0.94^{\mathrm{a}}$ & $7.4 \pm 0.37^{\mathrm{e}}$ & $28.4 \pm 1.09^{\mathrm{ab}}$ & $16.7^{\mathrm{a}} \pm 0.64^{\mathrm{d}}$ \\
\hline \multirow{2}{*}{ SPD80 } & 3 & $44.8 \pm 0.88^{\mathrm{a}}$ & $7.6 \pm 0.32^{\mathrm{e}}$ & $28.7 \pm 1.23^{\mathrm{ab}}$ & $15.3 \pm 0.45^{\mathrm{c}}$ \\
& 6 & $45.5 \pm 0.96^{\mathrm{a}}$ & $8.6 \pm 0.41^{\mathrm{f}}$ & $31.1 \pm 1.52^{\mathrm{cd}}$ & $14.8 \pm 0.46^{\mathrm{c}}$ \\
\hline \multirow{2}{*}{ SPF } & 3 & $62.3 \pm 1.27^{\mathrm{c}}$ & $1.5 \pm 0.12^{\mathrm{a}}$ & $29.6 \pm 1.19^{\mathrm{bc}}$ & $5.9 \pm 0.38^{\mathrm{b}}$ \\
& 6 & $60.9 \pm 1.33^{\mathrm{bc}}$ & $2.6 \pm 0.22^{\mathrm{b}}$ & $32.2 \pm 1.07^{\mathrm{d}}$ & $4.4 \pm 0.31^{\mathrm{a}}$ \\
\hline
\end{tabular}

SPD40, SPD60 and SPD80—sprouts air dried at 40,60 and $80{ }^{\circ} \mathrm{C}$, respectively, SPF-freeze-dried sprouts. Means with different letter in the same column are significantly different $(\alpha=0.05)$.

\subsection{TPC and AC}

Germination caused an increase in the TPC and enhanced AA (Table 5). Other studies have also reported that sprouting increases TPC and AA of different seeds [7,58]. Moreover, Vale et al. [11] found that broccoli sprouts germinated under dark conditions are characterized by higher level of phenolic compounds than those germinated under light conditions. The highest value of TPC was obtained for the extract obtained from 6-day sprouts + freeze-dried and 6-day sprouts + air-dried at $40{ }^{\circ} \mathrm{C}$ (14.7 and $14.2 \mathrm{mg} \mathrm{GAE} / \mathrm{g} \mathrm{DM}$, respectively). Sprouts obtained after 6 days of germination were characterized by higher values of TPC and AA than that of 3-day germinated broccoli seeds. Vale et al. [11] reported similar results for kale sprouts. The highest AC (the lowest values of EC50) was obtained for freeze-dried sprouts. This tendency was found for all the methods applied to test AA. The average values of EC50 for seeds were 164.3, 76.3 and $53.3 \mathrm{mg} \mathrm{DM} / \mathrm{mm}$, for ABTS, CHEL and RED, respectively. The values of 6-day germinated + freeze-dried broccoli sprouts were as follows: 104.2, 57.3 and $31.2 \mathrm{mg} \mathrm{DM} / \mathrm{mm}$ respectively for ABTS, CHEL and RED. Only some works concerning drying process of sprouts are reported.

An increase in the drying temperature to up $80^{\circ} \mathrm{C}$ caused a decrease in both TPC and AA, whereas an increase from 40 to $60^{\circ} \mathrm{C}$ had little or no significant effect on the values of TPC and AA. Złotek et al. [21] found that drying temperature up to $45^{\circ} \mathrm{C}$ has no significant influence on TPC and AC in extracts obtained from quinoa sprouts. Mattioli et al. [20] revealed, that that lyophilization better maintains the content of bioactive compounds compared to air-drying. On the other hand, Gan et al. [59] found that hot air-drying (at 70 and $80^{\circ} \mathrm{C}$ ) increased TPC and AA in mung bean sprouts in comparison to freeze-dried sprouts. Their explained this phenomenon as a result of sprouts browning during drying (Maillard reaction). 
Table 5. Total phenolics content and antioxidant activity of seeds and dried sprouts.

\begin{tabular}{|c|c|c|c|c|c|}
\hline Sample & $\begin{array}{l}\text { Germination } \\
\text { Time (Days) }\end{array}$ & $\begin{array}{c}\text { TPC } \\
\text { (mg GAE/g DM) }\end{array}$ & $\begin{array}{c}\text { ABTS EC } 50 \\
(\mathrm{mg} \mathrm{DM} / \mathrm{mL})\end{array}$ & $\begin{array}{c}\text { CHEL EC }_{50} \\
(\mathrm{mg} \mathrm{DM} / \mathrm{mL})\end{array}$ & $\begin{array}{c}\text { RED } \\
(\mathrm{mg} \mathrm{DM} / \mathrm{mL})\end{array}$ \\
\hline Seeds & - & $7.6 \pm 0.26^{a}$ & $164.3 \pm 6.8^{h}$ & $76.3 \pm 3.7^{\mathrm{e}}$ & $53.2 \pm 2.1^{\mathrm{e}}$ \\
\hline \multirow{2}{*}{ Fresh sprouts } & 3 & $12.6 \pm 044^{\mathrm{e}}$ & $111.2 \pm 4.3^{c}$ & $48.8 \pm 2.6^{b}$ & $28.4 \pm 1.2^{a}$ \\
\hline & 6 & $13.5 \pm 0.39 \mathrm{fg}$ & $99.7 \pm 4.2^{\mathrm{a}}$ & $56.7 \pm 2.8^{c}$ & $30.6 \pm 2.5^{a b}$ \\
\hline \multirow{2}{*}{ SPD40 } & 3 & $11.8 \pm 0.36^{\mathrm{cd}}$ & $125.8 \pm 6.2^{\mathrm{e}}$ & $65.6 \pm 4.2^{d}$ & $30.1 \pm 1.6^{a}$ \\
\hline & 6 & $14.2 \pm 0.28^{g}$ & $119.6 \pm 5.7^{\mathrm{cd}}$ & $72.3 \pm 4.1^{\mathrm{e}}$ & $32.8 \pm 1.5^{\mathrm{cd}}$ \\
\hline \multirow{2}{*}{ SPD60 } & 3 & $11.4 \pm 0.42^{c}$ & $132.3 \pm 5.8^{f}$ & $88.4 \pm 4.8^{f}$ & $31.7 \pm 1.8^{b c}$ \\
\hline & 6 & $12.5 \pm 0.18^{\mathrm{e}}$ & $117.8 \pm 4.5^{\mathrm{cd}}$ & $91.4 \pm 4.5^{f}$ & $32.6 \pm 1.1^{b c}$ \\
\hline \multirow{2}{*}{ SPD80 } & 3 & $10.4 \pm 0.12^{b}$ & $150.9 \pm 6.7^{g}$ & $112.5 \pm 5.3 \mathrm{~g}$ & $33.2 \pm 1.3^{b c}$ \\
\hline & 6 & $13.1 \pm 0.21^{\mathrm{f}}$ & $146.7 \pm 6.3^{g}$ & $132.8 \pm 4.2^{h}$ & $35.6 \pm 1.6^{\mathrm{d}}$ \\
\hline \multirow{2}{*}{ SPF } & 3 & $12.2 \pm 0.32 \mathrm{de}$ & $121.2 \pm 3.2 \mathrm{de}$ & $42.1 \pm 1.7^{a}$ & $30.5 \pm 0.7^{a}$ \\
\hline & 6 & $14.7 \pm 0.17^{h}$ & $104.2 \pm 5.2^{b}$ & $57.3 \pm 2.3^{c}$ & $31.2 \pm 1.9^{\mathrm{a}}$ \\
\hline
\end{tabular}

SPD40, SPD60 and SPD80—sprouts air dried at 40,60 and $80^{\circ} \mathrm{C}$, respectively, SPF-freeze-dried sprouts, TPC—-total phenolics content, ABTS—antiradical activity, CHEL—chelating power, RED—reducing power. Means with different letter in the same column are significantly different $(\alpha=0.05)$.

\section{Conclusions}

The Page model exhibited a very good fit to the experimental data obtained by both air-drying and freeze-drying techniques. The time of germination had less effect on the drying kinetics of the broccoli sprouts. According to our results, the broccoli sprouts showed lower values of specific grinding energy and exhibited a different grinding pattern in comparison to non-germinated seeds. More importantly, the highest efficiency of grinding was obtained for freeze-dried broccoli sprouts. In the case of color parameters, air-drying decreased the lightness of broccoli sprouts. An increase in the air-drying temperature from 60 to $80^{\circ} \mathrm{C}$ increased the redness and yellowness of the ground sprouts and caused a decrease in TPC and AC. The highest TPC and AA were observed in air-dried sprouts $\left(40{ }^{\circ} \mathrm{C}\right)$ and freeze-dried sprouts after 6 days of germination. The best quality broccoli sprouts powder was obtained using the freeze-drying technique, however, the powder obtained from BS air-dried at $40{ }^{\circ} \mathrm{C}$ also is recommended. Such a kind of material can be used as a functional additive in many food products.

Author Contributions: Conceptualization, D.D. and E.H.-K.; methodology, D.D.; validation, U.G.-D., A.M., Z.K., investigation, E.H.-K, D.D., U.G.-D., R.R. and W.H.H.; data curation, E.H.-K.; writing-original draft preparation, D.D.; writing-review and editing, A.M.; visualization, R.R. All authors have read and agreed to the published version of the manuscript.

Funding: This research received no external funding.

Conflicts of Interest: The authors declare no conflict of interest.

\section{References}

1. Šamec, D.; Pavlović, I.; Radojčić Redovniković, I.; Salopek-Sondi, B. Comparative analysis of phytochemicals and activity of endogenous enzymes associated with their stability, bioavailability and food quality in five brassicaceae sprouts. Food Chem. 2018, 269, 96-102. [CrossRef] [PubMed]

2. Tian, M.; Xu , X.; Liu, Y.; Xie, L.; Pan, S. Effect of se treatment on glucosinolate metabolism and health-promoting compounds in the broccoli sprouts of three cultivars. Food Chem. 2016, 190, 374-380. [CrossRef] [PubMed]

3. Steevens, J.; Schouten, L.J.; Goldbohm, R.A.; van den Brandt, P.A. Vegetables and fruits consumption and risk of esophageal and gastric cancer subtypes in the Netherlands Cohort Study. Int. J. Cancer 2011, 129, 2681-2693. [CrossRef] [PubMed]

4. Moon, J.K.; Kim, J.R.; Ahn, Y.J.; Shibamoto, T. Analysis and anti-Helicobacter activity of sulforaphane and related compounds present in broccoli (Brassica oleracea L.) sprouts. J. Agric. Food Chem. 2010, 58, 6672-6677. [CrossRef] 
5. Paśko, P.; Tyszka-Czochara, M.; Galanty, A.; Gdula-Argasińska, J.; Żmudzki, P.; Bartoń, H.; Zagrodzki, P.; Gorinstein, S. Comparative study of predominant phytochemical compounds and proapoptotic potential of broccoli sprouts and florets. Plant Foods Hum. Nutr. 2018, 73, 95-100. [CrossRef]

6. Ding, J.; Yang, T.; Feng, H.; Dong, M.; Slavin, M.; Xiong, S.; Zhao, S. Enhancing contents of $\gamma$-aminobutyric acid (GABA) and other micronutrients in dehulled rice during germination under normoxic and hypoxic conditions. J. Agric. Food Chem. 2016, 64, 1094-1102. [CrossRef]

7. Gawlik-Dziki, U.; Dziki, D.; Nowak, R.; Świeca, M.; Olech, M.; Pietrzak, W. Influence of sprouting and elicitation on phenolic acids profile and antioxidant activity of wheat seedlings. J. Cereal Sci. 2016, 70, 221-228. [CrossRef]

8. Bohn, L.; Meyer, A.S.; Rasmussen, S.K. Phytate: Impact on environment and human nutrition. A challenge for molecular breeding. J. Zhejiang Univ. Sci. B. 2008, 9, 165-191. [CrossRef]

9. Grewal, A.; Jood, S. Effect of processing treatments on nutritional and antinutritional contents of green gram. J. Food Biochem. 2006, 30, 535-546. [CrossRef]

10. Gawlik-Dziki, U.; Świeca, M.; Dziki, D.; Sugier, D. Improvement of nutraceutical value of broccoli sprouts by natural elicitors. Acta Sci. Pol. Hortoru. 2013, 12, 129-140.

11. Vale, A.P.; Santos, J.; Melia, N.; Peixoto, V.; Brito, N.V.; Beatriz, M.; Oliveira, P.P. Phytochemical composition and antimicrobial properties of four varieties of brassica oleracea sprouts. Food Control 2015, 55, 248-256. [CrossRef]

12. Baenas, N.; Moreno, D.A.; García-Viguera, C. Selecting sprouts of Brassicaceae for optimum phytochemical composition. J. Agric. Food Chem. 2012, 60, 11409-11420. [CrossRef]

13. Hassini, I.; Martinez-Ballesta, M.C.; Boughanmi, N.; Moreno, D.A.; Carvajal, M. Improvement of broccoli sprouts (Brassica oleracea L. var. italica) growth and quality by $\mathrm{KCl}$ seed priming and methyl jasmonate under salinity stress. Sci. Hortic. Amst. 2017, 226, 141-151. [CrossRef]

14. Bello, C.; Maldini, M.; Baima, S.; Scaccini, C.; Natella, F. Glucoraphanin and sulforaphane evolution during juice preparation from broccoli sprouts. Food Chem. 2018, 268, 249-256. [CrossRef]

15. Liang, H.; Wei, Y.; Li, R.; Cheng, L.; Yuan, Q.; Zheng, F. Intensifying sulforaphane formation in broccoli sprouts by using other cruciferous sprouts additions. Food Sci. Biotechnol. 2018, 27, 957-962. [CrossRef] [PubMed]

16. Murashima, M.; Watanabe, S.; Zhuo, X.G.; Uehara, M.; Kurashige, A. Phase 1 study of multiple biomarkers for metabolism and oxidative stress after one-week intake of broccoli sprouts. Biofactors 2004, 22, 271-275. [CrossRef] [PubMed]

17. Marton, M.; Mandoki, Z.S.; Csapo-Kiss, Z.S.; Csapo, J. The role of sprouts in human nutrition. A review. Acta Univ. Sapientiae Aliment. 2010, 3, 81-117.

18. Chan, E.W.C.; Lim, Y.Y.; Wong, S.K.; Lim, K.K.; Tan, S.P.; Lianto, F.S.; Yong, M.Y. Effects of different drying methods on the antioxidant properties of leaves and tea of ginger species. Food Chem. 2009, 113, 166-172. [CrossRef]

19. Valdenegro, M.; Almonacid, S.; Henríquez, C.; Lutz, M.; Fuentes, L.; Simpson, R. The effects of drying processes on organoleptic characteristics and the health quality of food ingredients obtained from goldenberry fruits (Physalis peruviana). Open Access Sci. Rep. 2013, 2, 2.

20. Mattioli, S.; Dal Bosco, A.; Castellini, C.; Falcinelli, B.; Sileoni, V.; Marconi, O.; Mancinelli, A.C.; Cotozzolo, E.; Benincasa, P. Effect of heat- and freeze-drying treatments on phytochemical content and fatty acid profile of alfalfa and flax sprouts. J. Sci. Food Agric. 2019, 99, 4029-4035. [CrossRef]

21. Złotek, U.; Gawlik-Dziki, U.; Dziki, D.; Świeca, M.; Nowak, R.; Martinez, E. Influence of drying temperature on phenolic acids composition and antioxidant activity of sprouts and leaves of white and red quinoa. J. Chem. 2019. [CrossRef]

22. Awolu, O.O.; Manohar, B. Mechanical characteristics and grinding studies of mango seed kernel. Eng. Agric. Environ. Food 2018, 11, 256-261. [CrossRef]

23. Wu, S.C.; Wu, S.H.; Chau, C.F. Improvement of the hypocholesterolemic activities of two common fruit fibers by micronization processing. J. Agric. Food Chem. 2009, 57, 5610-5614. [CrossRef] [PubMed]

24. Platat, C.; Hillary, S.; Tomas-Barberan, F.A.; Martinez-Blazquez, J.A.; Al-Meqbali, F.; Souka, U.; Al-Hammadi, S.; Ibrahim, W. Urine metabolites and antioxidant effect after oral intake of date (phoenix dactylifera L.) seeds-based products (powder, bread and extract) by human. Nutrients 2019, 11. [CrossRef] [PubMed] 
25. Yang, J.; Jin, X.; Chen, X.D. Investigation of the effects of mechanical treatments on cellular structure integrity and vitamin C extractability of broccoli (Brassica oleracea L. var. Italica) by LF-NMR. Food Funct. 2018, 9, 2942-2950. [CrossRef]

26. Yu, L.; Gao, B.; Li, Y.; Wang, T.T.Y.; Luo, Y.; Wang, J.; Yu, L. Home food preparation techniques impacted the availability of natural antioxidants and bioactivities in kale and broccoli. Food Funct. 2018, 9, 585-593. [CrossRef]

27. Świeca, M.; Surdyka, M.; Gawlik-Dziki, U.; Złotek, U.; Baraniak, B. Antioxidant potential of fresh and stored lentil sprouts affected by elicitation with temperature stresses. Int. J. Food Sci. Tech. Technol. 2013, 49, 1811-1817. [CrossRef]

28. Dimov, Z.; Suprianto, E.; Hermann, F.; Möllers, C. Genetic variation for seed hull and fibre content in a collection of european winter oilseed rape material (Brassica napus L.) and development of NIRS calibrations. Plant Breed. 2012, 131, 361-368. [CrossRef]

29. Kowalski, S.J. Intensification of drying processes due to ultrasound enhancement. Chem. Process Eng. 2018, 39, 251-262.

30. Rudy, S.; Dziki, D.; Krzykowski, A.; Gawlik-Dziki, U.; Polak, R.; Różyło, R.; Kulig, R. Influence of pre-treatments and freeze-drying temperature on the process kinetics and selected physico-chemical properties of cranberries (Vaccinium macrocarpon ait.). LWT Food Sci. Technol. 2015, 63, 497-503. [CrossRef]

31. Sarimeseli, A. Microwave drying characteristics of coriander (Coriandrum sativum L.) leaves. Energ. Convers. Manag. 2011, 52, 1449-1453. [CrossRef]

32. Dziki, D.; Gawlik-Dziki, U.; Różyło, R.; Miś, A. Drying and grinding characteristics of four-day-germinated and crushed wheat: A novel approach for producing sprouted flour. Cereal Chem. 2015, 92, 312-319. [CrossRef]

33. Dziki, D.; Polak, R.; Rudy, S.; Krzykowski, A.; Gawlik-Dziki, U.; Rózyło, R.; Miś, A.; Combrzyński, M. Simulation of the process kinetics and analysis of physicochemical properties in the freeze drying of kale. Int. Agrophys. 2018, 32, 49-56. [CrossRef]

34. Adiletta, G.; Russo, P.; Senadeera, W.; Di Matteo, M. Drying characteristics and quality of grape under physical pretreatment. J. Food Eng. 2016, 172, 9-18. [CrossRef]

35. Adiletta, G.; Wijerathne, C.; Senadeera, W.; Russo, P.; Crescitelli, A.; Matteo, M.D. Dehydration and rehydration characteristics of pretreated pumpkin slices. Ital. J. Food Sci. 2018, 30, 684-706.

36. Doymaz, I. Drying kinetics of white mulberry. J. Food Eng. 2003, 61, 341-346. [CrossRef]

37. Dziki, D.; Miś, A.; Gładyszewska, B.; Laskowski, J.; Kwiatkowski, S.; Gawlik-Dziki, U. Physicochemical and grinding characteristics of dragonhead seeds. Int. Agrophs. 2013, 27, 403-408. [CrossRef]

38. Dziki, D. Effect of preliminary grinding of the wheat grain on the pulverizing process. J. Food Eng. 2011, 104, 585-591. [CrossRef]

39. Sokołowski, M. Energy consumed in grinding-A new idea of a general law of comminution-New tests stands and testing results. Récents Prog. Génie Procédés 1996, 10, 221-226.

40. Alibas, I. Microwave, vacuum, and air-drying characteristics of collard leaves. Drying Technol. 2009, 27, 1266-1273. [CrossRef]

41. Gawlik-Dziki, U.; Dziki, D.; Świeca, M.; Sęczyk, Ł.; Różyło, R.; Szymanowska, U. Bread enriched with Chenopodium quinoa leaves powder-The procedures for assessing the fortification efficiency. LWT Food Sci. Technol. 2015, 62, 1226-1234. [CrossRef]

42. Singleton, V.L.; Rossi, A. Colorimetry of total phenolics with phosphomolybdic-phosphotungstics acid reagents. Am. J. Enol. Vitic. 1965, 16, 144-158.

43. Guo, J.T.; Lee, H.L.; Chiang, S.H.; Lin, H.I.; Chang, C.Y. Antioxidant properties of the extracts from different parts of broccoli in Taiwan. J. Food Drug Anal. 2001, 9, 96-101.

44. Re, R.; Pellegrini, N.; Proteggente, A.; Pannala, A.; Yang, M.; Rice-Evans, C. Antioxidant activity applying an improved ABTS radical cation decolorization assay. Free Radic. Biol. Med. 1999, 26, 1231-1237. [CrossRef]

45. Oyaizu, M. Studies on products of browning reaction-Antioxidative activities of products of browning reaction prepared from glucosamine. Jpn. J. Nutr. 1986, 44, 307-315. [CrossRef]

46. Reale, A.; Di Renzo, T.; Preziuso, M.; Panfili, G.; Cipriano, L.; Messia, M.C. Stabilization of sourdough starter by spray drying technique: New breadmaking perspective. LWT Food Sci. Technol. 2019, 99, 468-475. [CrossRef] 
47. Rahman, M.S. Food stability beyond water activity and glass transtion: Macro-micro region concept in the state diagram. Int. J. Food Prop. 2009, 12, 726-740. [CrossRef]

48. Antal, T.; Tarek, M.; Tarek-Tilistyák, J.; Kerekes, B. Comparative effects of three different drying methods on drying kinetics and quality of jerusalem artichoke (Helianthus tuberosus L.). J. Food Process. Pres. 2017, 41, e12971. [CrossRef]

49. Izli, N.; Izli, G.; Taskin, O. Impact of different drying methods on the drying kinetics, color, total phenolic content and antioxidant capacity of pineapple. CYTA J. Food 2018, 16, 213-221. [CrossRef]

50. Różyło, R.; Rudy, S.; Krzykowski, A.; Dziki, D. Novel application of freeze-dried amaranth sourdough in gluten-free bread production. J. Food Process Eng. 2015, 38, 135-143. [CrossRef]

51. Neethirajan, S.; Jayas, D.S.; White, N.D.G. Detection of sprouted wheat kernels using soft X-ray image analysis. J. Food Eng. 2007, 81, 509-513. [CrossRef]

52. Dziki, D.; Laskowski, J. Study to analyze the influence of sprouting of the wheat grain on the grinding process. J. Food Eng. 2010, 96, 562-567. [CrossRef]

53. Abasi, S.; Minaei, S. Effect of drying temperature on mechanical properties of dried corn. Drying Technol. 2014, 32, 774-780. [CrossRef]

54. Valdivia-López, M.Á.; Tecante, A. Chia (Salvia hispanica): A review of native mexican seed and its nutritional and functional properties. Adv. Food Nutr. Res. 2015, 75, 53-75. [PubMed]

55. Chunthaworn, S.; Achariyaviriya, S.; Achariyaviriya, A.; Namsanguan, K. Color kinetics of longan flesh drying at high temperature. Pap. Presented Procedia Eng. 2012, 32, 104-111. [CrossRef]

56. Orak, H.H.; Aktas, T.; Yagar, H.; Isbilir, S.S.; Ekinci, N.; Sahin, F.H. Effects of hot air and freeze drying methods on antioxidant activity, colour and some nutritional characteristics of strawberry tree (arbutus unedo L) fruit. Food Sci. Technol. Int. 2012, 18, 391-402. [CrossRef]

57. Albanese, D.; Cinquanta, L.; Cuccurullo, G.; Di Matteo, M. Effects of microwave and hot- air-drying methods on color $\beta$-carotene and radical scavenging activity of apricots. Int. J. Food Sci. Tech. 2013, 48, 1327-1333. [CrossRef]

58. Falcinelli, B.; Maranghi, S.; Paoletti, A.; Marconi, O.; Rosati, A.; Famiani, F.; Benincasa, P. Sprouting olive (Olea europaea L.) seeds as a source of antioxidants from residual whole stones. Sci. Hortic. Amst. 2018, 240, 558-560. [CrossRef]

59. Gan, R.Y.; Lui, W.Y.; Chan, C.L.; Corke, H. Hot air drying induces browning and enhances phenolic content and antioxidant capacity in mung bean (Vigna radiata L.) sprouts. J. Food Process. Pres. 2016, 41. [CrossRef]

(C) 2020 by the authors. Licensee MDPI, Basel, Switzerland. This article is an open access article distributed under the terms and conditions of the Creative Commons Attribution (CC BY) license (http://creativecommons.org/licenses/by/4.0/). 